\title{
On the Persistence of the Genealogical in Contemporary Theology
}

\begin{abstract}
There is a persistence of genealogical discourse in a certain strand of contemporary theology. Opting for the genealogical shapes the theological task of remembrance and engagement with the historical tradition in important, but also problematic ways. In this article I discuss how genealogical discourse was appropriated by theology, and then uncover its implicit assumptions and tendencies. Analysing some encounters between theological genealogies and various Hegelian thinkers, I draw a contrast between Nietzschean genealogy and Hegelian 'phenomenology'. This comparison brings to light some fundamental ways in which the genealogical might distort theological writing and practice.
\end{abstract}

Word count: 10634 .

It is very easy to forget; even easier to remember wrongly. For theologians whose work involves remembering well, this fact might induce in us a combination of mourning and regret. Much is unintentionally lost to time, yet even more is wittingly let go in a deceitful attempt to cover up our tracks. The theological task must involve a keen attention to what we remember, how we so often run from our memories, and, importantly, the ways in which remembering takes place. Acts of remembrance are intertwined with their objects, and a critique of our practices of remembrance must involve considering the complexity of these relationships.

In The Anatomy of Misremembering: Von Balthasar's Response to Philosophical Modernity, Cyril O'Regan draws attention to the importance of remembering rightly. ${ }^{1}$ O'Regan is concerned with a certain 'misremembering' in modern thought, such that things are not merely displaced and forgotten, but seriously misconstrued-deliberately or not. Engaging with and learning from the work of Hans Urs von Balthasar, he seeks to remember the true sense of the memoria Dei, and thereby to avoid the dangers such an equivocal expression may present. Here the act of remembering is as important as its object. If theologians are concerned with the memory of God, we must always be sure to distinguish the subjective and objective senses of this genitive, lest our memory of God becomes wholly identified with God's own memory.

O'Regan's first interlocutor and object of critique in his project is G.W.F. Hegel, a thinker who has deeply shaped the habits and practices of theological remembrance. O'Regan recounts Balthasar's 'counter-genealogy' to the philosophical modernity of Hegel, and suggests that Balthasar reminds us of things not only forgotten, but misremembered by Hegel. O'Regan picks up the language of genealogy and thereby opts for a specific way of remembering, which itself must be evaluated. If we can designate the genealogical as a distinctive practice of remembrance, we must turn our eyes to the context in which this approach arose and the habits it instils. Should we learn anything from Hegel it must be that we must always keep an eye on how we ourselves remember. Although it might be right to charge Hegel with misremembering,

1 Cyril O'Regan, The Anatomy of Misremembering: Von Balthasar's Response to Philosophical Modernity (Chestnut Ridge, NY: Crossroad Pub, 2014). 
we must consider very carefully our own tendencies and misremembering. For there is a dimension to Hegel's philosophy which, as I will argue, O'Regan has not fully dealt with, perhaps because it is so at odds with important strands of contemporary academic theology.

The presence of genealogical discourse in contemporary theology has its root in a very specific academic milieu, arising as part of a larger project of finding a path forward for theology in a postmodern context. ${ }^{2}$ This was perhaps most clearly defended and introduced as a mode of theological discourse in the early work of John Milbank. In Theology and Social Theory, he opts for genealogical discourse in order to respond to and overcome the threat to theological reason posed by secular and poststructuralist thought. The rhetorical dimension of this move was to use a 'method' already present in secular discourse in order to subvert those discourses themselves. With genealogical discourse, however, came a set of implicit assumptions about what it means to remember history, culture and the presence of God in the world. While Milbank, O'Regan, and others write 'baptized' genealogies, little work has been done on the consequences of such a form of storytelling.

In order to discover what is at stake in this discussion, I will take a closer look at how and why genealogies gained a place of prominence on the academic scene, and how they built on an explicit rejection of modern rationality. In light of this, we can understand more accurately how genealogy became a fruitful mode of theological discourse and how Milbank, in particular, found a theological justification for such a move.

On this basis, I suggest that we must ask questions about the genealogical approach in theology today. A critique of the genealogical is especially pertinent given the emergence of a new form of Hegelian thought, perhaps most notably in the work of Slavoj Žižek. I am not interested in Žižek's work as such here, but how it constitutes a return of Hegelian thought which challenges and makes apparent the limitations of a genealogical approach in theology. Certain encounters between variations of Hegelian thought and a Christian genealogy in O'Regan's and Milbank's writings reveal some previously unrecognised problems. A form of deadlock, and even implausibility, in the face of Hegelian critique, points to the limits of the genealogical approach itself, irrespective of the specifics of the stories told. The eagerness to demonstrate what Hegel misremembered prevents a critical look at how a genealogical approach can skew our own memory. Looking at the work of Žižek will help us to see what is at stake because his is a Hegelianism after the failure of modern rationality. His rejection of genealogy demonstrates that this is not about the conflict between modern rationality and various postmodern

${ }^{2}$ Some examples of theological genealogies the last few decades: Giorgio Agamben, The Kingdom and the Glory: For a Theological Genealogy of Economy and Government / (Homo Sacer II, 2), Meridian, Crossing Aesthetics (Stanford, California: Stanford University Press, 2011); Conor Cunningham, Genealogy of Nihilism: Philosophies of Nothing and the Difference of Theology, Radical Orthodoxy Series (London; New York: Routledge, 2002); Alasdair C. MacIntyre, After Virtue: A Study in Moral Theory, Bloomsbury Revelations Series (London: Bloomsbury, 2011); Adrian Pabst, Metaphysics: The Creation of Hierarchy, Interventions (Grand Rapids, Mich: W.B. Eerdmans Pub. Co, 2012); Catherine Pickstock, After Writing: On the Liturgical Consummation of Philosophy, Challenges in Contemporary Theology (Oxford, UK ; Malden, Mass: Blackwell Publishers, 1998). Other works whose constructive intrests are a bit more muted: Olivier Boulnois, Etre et Représentation: Une Généalogie de La Métaphysique Moderne À L'époque de Duns Scot, XIIIe-XIVe Siècle, 1re éd, Epiméthée (Paris: Presses universitaires de France, 1999); Louis Dupré, Passage to Modernity: An Essay in the Hermeneutics of Nature and Culture (New Haven: Yale Univ. Press, 1993); Michael Allen Gillespie, The Theological Origins of Modernity (Chicago, Ill.: Univ. of Chicago Press, 2008). 
discourses, but rather about negotiating between the two major traditions of Nietzsche and Hegel in our contemporary intellectual situation.

The core issue is, therefore, the difference between a Nietzschean genealogy and what I will call a Hegelian 'phenomenology'. I will contend that opting for a Nietzschean genealogy results in genuine theological losses that distort our practice of remembrance, and hence that there is still something to be learned from Hegel. My assertion is not primarily that an arrival of a new kind of Hegelianism requires new tools with which to respond to an apologetic challenge. Nor is this an unequivocal defence of Hegel-such a defence would again run the risk of opting for one genealogical strand to the exclusion of the other. The point is rather that these encounters with the Hegelian tradition might remind us of some truths forgotten in following the postmodern tradition of purging ourselves of the Hegelian.

A word must be added about the seemingly inconsistent nature of questioning genealogies with what seems to be yet another genealogy. Is not my own argument simply just a genealogy about how genealogies arose, and then yet another plea for something 'lost' on the way - in my case a strand of Hegelian thinking? Yes, to some extent. To this, however, I would add that part of my aim here to question the tendency of genealogies to portray the 'wrong' line of descent as irredeemably wrong, while valorising another line as unequivocally good. I reject this tendency and can, therefore, admit that there is much to be learned from a genealogical approach, not to say actual genealogies written by theologians the past decades. Furthermore, my argument transitions from a short genealogy of genealogies, to a consideration of the particularities of some contemporary theological exchanges. The weight of my argument rests just as much on this part. The following analysis of what we have lost in opting for genealogies, and what we can learn from a Hegelian phenomenology is written with the recognition that we are always inheritors of a multitude of traditions and that there is always something to learn even from those traditions to which we would rather not listen. Let us now begin.

\section{GENEALOGY AFTER THE FAILURE OF CRITIQUE}

Many twentieth-century thinkers read Nietzsche as the initiator and prophet of a postmodern culture growing out of a dissatisfaction with the Enlightenment project of critique. What I call 'critique' in this context is the project of discerning truth by means of a rationality that transcends individual viewpoints and on the basis of which disagreement can in principle be negotiated and resolved. This critique required the notion of a trans- or super-linguistic and universal rationality. Granted, Nietzsche's dissatisfaction with this notion of universal reason had predecessors, as seen for example in Johann Georg Hamann's metacritique of Kant's critical philosophy, or Frederich Heinrich Jacobi's charge that modern reason leads to 'nihilism' in his Briefe über die Lehre Spinozas. ${ }^{3}$ Common to these attacks is the claim that a trans-linguistic and stable rationality is little more than a myth, and that the whole project of

\footnotetext{
${ }^{3}$ John Betz, After Enlightenment: The Post-Secular Vision of J.G. Hamann, Illuminations-Theory and Religion (Malden, MA; Oxford: Wiley-Blackwell Pub, 2009), 230-57; Johann Georg Hamann, Writings on Philosophy and Language, ed. Kenneth Haynes, Cambridge Texts in the History of Philosophy (Cambridge, UK ; New York: Cambridge University Press, 2007), 205-18; Friedrich Heinrich Jacobi, Werke, ed. Klaus Hammacher and Walter Jaeschke (Hamburg: Meiner, 1998), I.I. 130.
} 
modern critique fails the moment one sees the linguistic, cultural and contingent nature of modern reason.

For Nietzsche, this dissatisfaction with modern critique results in a novel rhetoric, which, although not omnipresent in his works, points to a new kind of discourse after Enlightenment rationality. Most famously in the Genealogy of Morals, Nietzsche relativizes ethical rationality when he tells the story of morality otherwise. ${ }^{4}$ But this new form of storytelling is not the story of a Phenomenology of Spirit which vindicates rationality by showing how it envelopes its historical failures within itself and thus transcends culture and language precisely by working in and through it, nor it is another narrative legitimization of knowledge in the terms of JeanFrançois Lyotard. With the Genealogy of Morals, we see the origins of a form of storytelling that challenges any legitimization of knowledge as such.

In 'What is Enlightenment?', Foucault - an important genealogist himself - argued that in late modernity, one is faced with the task of constructing a 'historical ontology' as a 'critique of what we are saying and doing'. ${ }^{5}$ This critique is a critique of limits, and thus a critique of critique, in so far as judging (krisis) always happens on the basis of a stable law or rule that provides limits for judgement. Instead of tracing the limits of knowledge, as in Kant's case, now we must ask 'in what is given to us as universal, obligatory, what place is occupied by whatever is singular, contingent and the product of arbitrary constraint?' We are thus taken from a delineation of what cannot be transgressed, to the opposite task of discovering what can be transgressed. This shift also constitutes a turn from a transcendental investigation of the supra-historical structures of reason to one of history: now the task is to show that the ways in which we think, speak and live are not universally necessary; that they are products of contingent and arbitrary historical changes. ${ }^{6}$ A narrative legitimation of the universal and eternal truths of reason is turned on its head and becomes a genealogical destabilisation of those very truths. It is in this sense that genealogy becomes the central philosophical 'design'.

Contingency is the focal point for the genealogical approach; for it is explicitly set in contrast to any developmental or evolutionary approach. In his 'Nietzsche, Genealogy, History' Foucault traces the important (though sometimes conflated) distinction between Herkunft and Ursprung in Nietzsche's work: A genealogy should not trace the Ursprung or the origin of a way of living or thinking. The notion of an origin implies the fixed essence of something that has appeared, but that is precisely what the genealogical approach rules out. ${ }^{7}$ A genealogical critique cannot be reduced to an attempt to locate the precise origin of an idea, whether to establish or discredit that idea. Instead, genealogies trace Herkunft, the descent of an idea, tradition, group or way of living, showing how there are no stable essences or origins to be found. Unlike a story that valorises a certain concept, object or a person by tracing its heritage, Nietzsche's genealogy does quite the opposite: showing how the elements of the world we

\footnotetext{
${ }^{4}$ Friedrich Wilhelm Nietzsche, Keith Ansell-Pearson, and Carol Diethe, On the Genealogy of Morality, Rev. student ed, Cambridge Texts in the History of Political Thought (Cambridge ; New York: Cambridge University Press, 2007).

${ }^{5}$ Michel Foucault and Paul Rabinow, "What Is Enlightenment?," in The Foucault Reader: An Introduction to Foucault's Thought (London: Penguin Books, 1991), 45.

${ }^{6}$ Ibid., 46.

${ }^{7}$ Michel Foucault and Paul Rabinow, "Nietzsche, Genealogy, History," in The Foucault Reader: An Introduction to Foucault's Thought (London: Penguin Books, 1991), 76-100.
} 
inhabit stem from not just one origin, but a constant conjunction of origins or forces. ${ }^{8}$ In the Nietzschean tradition, the genealogical exhibits how the various forms of life and thinking are expressions of will(s) to power. Now the task is to trace the coming to be and passing away of things so that how we live, speak and think is gradually seen for what it is: radically contingent.

The genealogical form and Foucault's distinctive 'discourse analysis' appeared in an academic landscape dominated by ahistorical analysis. Sociological analysis and Marxist ideological critique relied on distinctions between historical articulations and ahistorical substrata from which to launch the critique. When Foucault effectively replaced terms such as 'ideology' and 'culture' with 'discourse' it was a part of his project of historicizing analysis and demonstrating the possibility of transgressing the constraint of ahistorical foundations, whether they were $a$ priori transcendental conditions, the immanent movement of dialectics or the analysis of base and superstructure. Yet because he was able to attend to that which tried to escape symbolisation and destabilisation by tracing the historical rootedness of the 'a priori' and alterations of episteme, his discourse analysis accounted for much of what was valuable in ideology critique without recourse to synchronic explanations and access to non-symbolised and ahistorical realms.

The significant trade-off, however, was to 'horizontalize' critique, indeed, to convert critique into analysis. Discourse analysis and genealogy with it are horizontal because it does not distinguish between a realm of 'ideology' or a symbolic and discursive domain, on the one hand, and a non-ideological domain on the other - a distinction which, as mentioned, seems to be the condition of possibility for any critique. To put it differently: there is nothing 'beneath' or 'beyond' discourse, such that even a genealogical 'critique' is really just a way of showing how every discourse which claims its ahistorical grounding in a stable substrate-including the genealogy itself! - relies on another set of linguistic configurations that is historically situated and therefore radically contingent. The result, then, is a radically immanentist and pluralist conception: there is nothing beyond the multitude of stories, symbols and culturally and bodily conditioned practices. Discourse analysis therefore also rejected the notion of ideology because in one sense everything became ideological, and yet, if there is a corresponding notion of ideology in discourse analysis, it must be defined as those discourses that claim for themselves privileged access to a non- or extra-discursive realm. This is the point at which the genealogical design kicks in and shows how the supposedly non-ideological realm is already the result of various textual or discursive devices.

\section{THEOLOGY AND GENEALOGY}

This is the background against which we need to understand the appropriation of genealogical critique in theological discourse, as is evident in Milbank's explicit dialogue with and criticism of postmodern thought in Theology and Social Theory. After a long crescendo, wherein he critically out-narrates political liberalism, positivism, and dialectics, the argument finally becomes self-reflective. Under the chapter title 'Ontological Violence or the Postmodern Problematic' - a chapter grouped together in the same section ('Theology and Difference') as his own proposal-, Milbank begins discussing 'method', for it is through and in the postmodern problematic that Milbank discovers a way of establishing a theological discourse.

\footnotetext{
${ }^{8}$ Cf. Raymond Geuss, "Nietzsche and Genealogy," in Morality, Culture, and History: Essays on German Philosophy (Cambridge, U.K. ; New York: Cambridge University Press, 1999), 128.
} 
Approaching the postmodern, treated as a single philosophy, Milbank dissects it into two aspects:

On the one hand, a historicist 'genealogy', on the other hand an 'ontology of difference', the two being interconnected in a fashion somewhat analogous to the relation between Hegel's Phenomenology and Hegel's Logic. ${ }^{9}$

Leaving aside the intriguing, yet contentious analogy with Hegel for now, we note that this two-aspect interpretation of postmodern philosophy becomes a minimal standard for how a post-Nietzschean philosophy or theology ought to proceed.

However, Milbank points out the insufficiency of a purely historicist genealogy: even in Nietzsche there is a strong evaluative aspect. Why should the whole of history, or every event be understood as 'an event of war?', Milbank asks. The answer is that Nietzsche has 'transcendentally understood all differences as negatively related'. ${ }^{10}$ The historicist narrative is therefore supplied with an ontology of violence, hidden under the apparent neutrality of genealogy. This veiling of a deeper mythos driving the evaluations of the narrative is necessary to distract us from the vacuous nature of any claim on the part of the postmoderns that their genealogy is binding.

Here is really the opening gambit of Milbank's play: if the postmodern problematic can be reduced to a historicist genealogy of violence founded in a mythos of ontological violent difference, there is nothing stopping him from telling a different story on the basis of an 'ontology of peace', since the notion of a universally binding rationality is by definition ruled out of the game. To the Genealogy of Morals, Milbank now proposes a new City of God. To the 'logic' of postmodern difference based on a univocity of being, he opposes a metaphysic of analogical difference.

Milbank's appropriation of genealogical discourse is, therefore, an attempt to join forces with the postmodern attack on modern liberal reason, while simultaneously out-flanking postmodern philosophers by challenging them on their own turf. Notably, rational argumentation is turned into an act of rhetorical performance, for there is no universal rational basis on which the Christian mythos can be shown to be a true one. At the same time, this is no collapse to relativism because the persuasiveness of the rhetorical performance is theologically grounded in the desire of creatures for God, and thus the Christian genealogical account is ultimately a story that attracts by virtue of its own beauty. It is roughly this understanding, I suggest, that must ground an appropriation of the genealogical for theology. ${ }^{11}$

However, whilst there is no clear sign of the decline of the Foucauldian tradition, which lives on in a variety of contemporary thinkers, as we shall see, the rise of a new form of Hegelian

\footnotetext{
${ }^{9}$ John Milbank, Theology and Social Theory: Beyond Secular Reason, 2nd ed (Oxford, UK ; Malden, MA: Blackwell Pub, 2006), 278.

${ }^{10}$ Ibid., 290.

${ }^{11}$ I do admit that there are other moments of the dialectical, the symbolical and other rhetorical directions in Milbank's greater oeuvre that at times upsets this primacy of the genealogical narrative signalled in Theology and Social Theory. My readings of Milbank must therefore be taken in the context of my attempt to bring out the specific tendencies of the genealogical. A fuller appreciation of Milbank's works is likely to complicate my reading in important ways.
} 
philosophy, most notably in the work of Slavoj Žižek, causes issues for a 'method' so clearly shaped as a response to a Nietzschean and postmodern context. ${ }^{12}$

\section{THE LIMITS OF GENEALOGY}

In The Anatomy of Misremembering, the first volume of his project of creatively tracing Balthasar's philosophical response to modernity, Cyril O'Regan aligns himself with the work of David Bentley Hart and shows appreciation for Milbank's genealogical approach. ${ }^{13}$ His project, therefore, proceeds with a similar genealogical approach to that of Milbank, but this time applying it in a sustained critique of Hegelian thought. According to O'Regan, Balthasar 'enters the Hegelian sanctuary, tells the story otherwise, and by doing so achieves a result considerably more hospitable to Christianity. ${ }^{14}$

Why this approach? Genealogy, O'Regan claims, is 'almost coincident with the Western tradition of discourse,' and therefore so pervasive that the philosopher or theologian cannot avoid it. Here the Phenomenology is listed as Hegel's most explicit genealogy, a text which is later 'genealogically outnarrated' by postmodern philosophers such as Nietzsche, Derrida, and Lyotard. ${ }^{15} \mathrm{O}$ 'Regan takes genealogy for granted as a form of theological discourse, indubitably because he is already inspired by his theological contemporaries. But in a perplexing turn of phrase, he baptises it a 'particular kind of supporting argument', a discourse the theologian turns to in support of his 'procedural', and substantive arguments. Genealogy functions, he says, by tracing the origins of the forms of practice, discourses, and ideas that the genealogist seeks to defend or subvert.

This interpretation of genealogical discourse is not entirely accurate, and it also fails to address a series of methodological questions such an interpretation raises. If the genealogy is accorded secondary status, merely supporting a primary procedural argument, then one must ask what force such a story carries. A more primary form of procedural rationality would suggest a rational dialectic in light of which the genealogy would pale, with the risk of it being brushed away as a somewhat pretentious performance in the history of ideas. How does it not become mere posturing? Furthermore, if a more primary form of reasoning is admitted, must not this procedural rationality face the same genealogical torment of the postmoderns? Is it not the very function of such a genealogy to subvert 'procedural' rationality?

Besides the complexities facing O'Regan when he grants genealogy a secondary role and thereby executes a wholly different project from that of Nietzsche and Foucault on the one hand, and Milbank and Hart on the other, his project could also benefit from a closer analysis of the relation between Hegel and a genealogical critique. Granted that we understand the role of genealogy broadly in the sense defended by Milbank, and not in the subordinate sense O'Regan defends, has not O'Regan still bypassed the real challenge of Hegel? If one can overcome Hegel simply by 'telling the story otherwise', that is, by remembering something Hegel has forgotten, then Hegel has already been defeated. The competition of genealogies

\footnotetext{
${ }^{12}$ I am aware of the problems of using the word 'method' in this context. For, as we shall see presently, a theological appropriation of genealogy fails if it is treated as mere 'method'.

${ }^{13}$ O'Regan, The Anatomy of Misremembering, 22-23.

${ }^{14}$ Ibid., 53.

${ }^{15}$ Ibid., 50.
} 
assumes the impossibility of Hegelian critique, and by so staging the encounter between Balthasar and Hegel, he ensures Hegel's loss from the start.

Hegel would be the first to claim that his story of the Western world, whether in his Phenomenology of Spirit or other works, read genealogically in O'Regan's sense, carries no weight at all. Consequently, a Balthasarian counter-genealogy provides little argumentative force because it has no original genealogy to oppose. Instead, O'Regan has already rendered Hegel mute by transposing the argument into a genealogical mode. This discursive approach to Hegel was already present in his magisterial The Heterodox Hegel, and is a common feature of how O'Regan analyses historical works. ${ }^{16}$ The result is that, on the one hand, the job is already done when he stages the dispute as one of competing genealogies since genealogy properly understood is built on the Nietzschean critique of the modern project. On the other hand, since O'Regan does not face the possibility of genealogical critique becoming vacuous unless the primacy of genealogy over substantial rationality is assumed, nothing is done at all: the Hegelian can simply wait for him to finish this 'supporting argument', and then ask for him to present his 'procedural' and primary arguments in the realm of dialectics. O'Regan never asks whether this move away from dialectics and Enlightenment reason to a genealogical historicism and a primacy of mythos is legitimate. Although his book is impressive and helpful in all sorts of ways, these methodological issues must be addressed, lest the project whole should be reduced to a reconstruction of various pieces of a genealogical puzzle from Balthasar's work.

We similarly see the dilemma facing a genealogical approach in a very interesting exchange between Milbank and Žižek. Although the debate, which takes place in The Monstrosity of Christ, deserves closer attention than what I can give it here, we find a perfect example of how a contemporary Hegelianism can claim to find a path beyond the apparent deadlock of opposing genealogies. ${ }^{17}$ After an essay from each of the interlocutors, in which they debate everything from the true nature of Christianity to dialectics versus analogy and the place of Meister Eckhart in the history of ideas, Žižek reflects on how to go forward:

It may appear that, in a theoretical debate, one reaches a dead end when the two opponents are reduced to their basic presuppositions-at this point, every argumentation, inclusive of "immanent critique," is superfluous; each of the two is reduced to his/her "here I stand," about which the other cannot do anything without relying on his/her own ultimate presuppositions, on his/her own "here I stand." However, a truly Hegelian approach does allow for an option here, the one of denying the obvious, of claiming: "You say this is your position, but it is not true-you do not have a position at all!" That is to say, one denies that it is possible at all to truly advocate the opponent's position-something that resembles the immortal answer of the interrogator to Winston Smith's query "Does Big Brother really exist?" from 1984: "It is YOU who doesn't exist!"18

Žižek's refusal to remain with this deadlock closely corresponds to his criticism of Milbank's polemic: 'the gap that separates us is most clearly discernible in the opposite cases: when

${ }^{16}$ Cyril O'Regan, The Heterodox Hegel, SUNY Series in Hegelian Studies (Albany: State University of New York Press, 1994).

${ }^{17}$ Slavoj Žižek, John Milbank, and Creston Davis, eds., The Monstrosity of Christ: Paradox or Dialectic?, Short Circuits (Cambridge, Mass.: MIT Press, 2009).

${ }^{18}$ Ibid., 235. 
Milbank criticises me simply for what I claim, as if my position is self-evidently untenable. ${ }^{\text {19 }}$ As both of them see, this is precisely the gap between a genealogical approach and a left-wing Hegelian critique: If there is no accessible surplus to discourse - that is, no extra-linguistic position from which to critique competing claims - the possibility of a deadlock on 'rational' grounds is real, and in that case, the interlocutors may have to be content with denouncing each other's narratives. It is here, however, that Žižek sees a path forward, to which we will turn in a moment.

O'Regan, incidentally, reviewed the Žižek-Milbank exchange. In an insightful analysis, referring to the interpretative dispute about Meister Eckhart which played a big part of the exchange, he asks 'what happens should Žižek offer the more persuasive reading of Eckhart?'20 The question is perhaps more pertinent than O'Regan himself realises, if my criticisms of him are correct. His point is that for Milbank the narrative emplotment of Eckhart in Milbank's story of Christianity is more than a historical dispute - it is a part of the very rhetorical force his argument, which happens to be the only kind of 'force' that Milbank ultimately can admit. Nevertheless, O'Regan's analysis of the potential yield of Milbank's strategy is not as convincing. While O'Regan thinks the upshot of a successful outcome of Milbank's performance is 'to upset Žižek's Protestant metanarrative of Orthodoxy-CatholicismProtestantism at its strongest point and make him incur something like a defeat' ${ }^{21}$ I suggest Žižek's reading of Christianity was never a 'metanarrative' in the first place: it was a phenomenological subversion of Milbank's orthodox narrative.

\section{HEGELIANISM AFTER THE END OF CRITIQUE}

I take an interest in Žižek because his represents a Hegelianism after the end of Enlightenment rationality. At the same time, his project signals a discontentment with the Twentieth-century turn to the linguistic and its total rejection of critique. ${ }^{22}$ While he is a Marxist or left-wing Hegelian in some sense, his Hegelianism takes quite a different shape from the Hegelian modernity which came under attack from postmodern thought. I am not so much interested in the details of Žižek's project as tracing what exactly he is affirming that those in the Nietzschean tradition deny, a difference which now cannot be reduced to the question of universal reason.

Žižek does not challenge the Foucauldian claim about the universality of discourse, nor does he postulate a non-linguistic or non-ideological domain from which one can adjudicate between positions. Still, contrary to the Nietzschean tradition he does think there is a peculiar moment of excess to discourse (or the 'Symbolic'), which allows him to postulate a new form of critique. Here Žižek combines Hegel and Lacanian psychoanalysis in order to postulate this

\footnotetext{
${ }^{19}$ Ibid.

${ }^{20}$ Cyril O'Regan, “Zizek and Milbank and the Hegelian Death of God,” Modern Theology 30, no. 4 (2010): 285.

${ }^{21}$ Ibid.

${ }^{22}$ I grant that the Foucaldian, anti-Hegelian legacy is very much alive. One example is the work of Giorgio Agamben. Here the discontentment with not being able to transgress the realm of discourse is tackled head on, by reformulating the problem of the ineffable and unsayable 'beyond' of language to a task immanent to discourse itself (defined as the problem of the 'infancy' of language). Cf. Giorgio Agamben, Infancy and History: The Destruction of Experience (London; New York: Verso, 1993).
} 
moment of excess without claiming that this transgression of the immanent discursive realm puts us in touch with a substantive and non-ideological reality. Instead, there lies in every moment of thinking a possibility of the appearance of the Lacanian 'Real', a moment when the linguistic configuration in question shows itself as appearance. The Real, as the moment where the symbolic realm is transgressed, is just this moment of appearance as appearance:

Therein resides Plato's deep insight: Ideas are not the hidden reality beneath appearances ... Ideas are nothing but the very form as such-or, as Lacan succinctly rendered Plato's point, the supra-sensible is appearance as appearance. ${ }^{23}$

Every symbolic construct can possibly reveal itself as appearance, as a construct that is veiling something. In a turn of phrase that could have been taken from some work of Christian theology, Žižek claims that "reality is never directly "itself". ${ }^{24}$ This requires a kind of tension or break which creates the possibility of the reflexive 'as' of appearance as appearance. There must be something against which the Symbolic can be understood as appearing, or more precisely as veiling something behind its appearing. While no non-ideological or nondiscursive domain exists, and so no hard reality in light of which the symbolic construct can show itself as appearance, nonetheless, for any such construct there arises a crack, inconsistency or incompleteness where it reveals itself as ideology.

This is the moment when the Real shows itself, but the Real is just this incompleteness of the Symbolic. The Real is empty or nowhere, it is not a positive place from which one can judge what is true. The Real is the 'irrepresentable $X$ ' as such - the non-symbolized remainder of every construct which provides us with 'a place that enables us to maintain a distance' from ideology and so affirm that it 'is not all. ${ }^{25}$ Žižek therefore affirms just enough distance from the discursive to judge ideology as ideology, without staking out another position or perspective. Within the ideologically constructed realm, therefore, there are always possibilities for failure - a glitch in the Matrix - if you like, where the constructed, immanent world betrays its inability to cover up a crack at the heart of being.

In light of this brief outline, we can see how this almost inverted Hegelianism differs from both old Marxist ideology critique and Foucauldian genealogy critique: according to this account, the old left-wing ideology critique failed because it confused the effective nature of appearance as such with the notion of a truth behind appearance, that is, with a subterranean materialist reality. ${ }^{26}$ Žižek couples a radical denial of the non-ideological with a strong theory of how ideologies still function just in virtue of being appearances. On the other hand, discourse analysis failed because it refused to imagine a different 'externality' from that proposed by Enlightenment reason. Having historicized every rational a priori, the universality of discourse seemed to rule out critique, properly understood. This new Hegelianism, however, is based on the claim that there might still be a place for critique if one returns to an ontology of radical brokenness.

${ }^{23}$ Slavoj Žižek, Less than Nothing: Hegel and the Shadow of Dialectical Materialism (London; New York: Verso, 2012), 31.

${ }^{24}$ Slavoj Zižek, "The Spectre of Ideology," in Mapping Ideology, ed. Slavoj Zižek, Mapping (London; New York: Verso, 1994), 21.

${ }^{25}$ Ibid., 17.

${ }^{26}$ Fabio Vighi and Heiko Feldner, "Ideology Critique or Discourse Analysis? Žižek against Foucault," European Journal of Political Theory 6, no. 2 (2007): 147. 
The crucial difference between the Hegelian tradition and the tradition from which the genealogical approach arose, then, is that the former affirms the possibility of maintaining some form of distance to the immanent discursive realm which it can be considered as such, and therefore a moment in which something might be learned. I want to stress again, however, that this return of Hegelian critique is by no means the return to a notion of universal reason as if dialectical reason has suddenly achieved its own self-legitimisation-although this hope of course lingers on in the right wing liberal interpretations of Hegel. Hence the Nietzschean tradition is to some extent given its due, something which finds its clearest expression in Žižek's acknowledging the universal nature of ideology and the emptiness and indeterminacy of the non-ideological space.

As a result, the possibility of critique is, as all post-Enlightenment philosophy, based on a wager. At this point might we not ask whether we are simply back to historicism? Any attempt on the part of the Hegelian to legitimise the possibility could surely be contested by historicizing the 'transcendentals' on which the legitimisation rests? Yes, that is strictly speaking true. But that does not force the Hegelian to adopt discourse analysis and genealogical historicism since there is no position from which to judge the post-rational Lacanian-Hegelian project less adequate than historicism. This wager, which any post-Nietzschean philosophy must admit lest it should return to the Enlightenment project, is clearly admitted by Žižek in his response to Gérad Lebrun's Nietzschean critique of Hegel. Lebrun tries to overcome Hegelianism through a Foucauldian and non-ontological reading of Nietzsche, on which basis he can claim that already with Hegel's dialectic a series of 'semantic decisions' have been taken. ${ }^{27}$ Žižek's riposte is not to deny that there is no radically contingent semantic decision before dialectics but rather that the whole point of Hegel's philosophy is to show what happens when we make these fundamental semantic decisions:

If there is a "semantic choice" that underlies Hegel's thought, it is not the desperate wager that, retroactively, one will be able to tell a consistent, all-encompassing and meaningful story in which every detail will be allotted to its proper place, but, on the contrary, the weird certainty ... that, with every figure of consciousness or form of life, things will always somehow "go wrong," that each position will generate an excess which will augur its self-destruction. ${ }^{28}$

This 'weird certainty' puts a wedge between the liberal reading of Hegel that still believes in universal reason and the one of Žižek's since the possibility of a Hegelian philosophy after Nietzsche cannot be established on purely rational grounds. Nevertheless, what the Hegelian can do, and what Žižek does, is to provide a counter-reading of history which is not a genealogy, but a Hegelian phenomenology. ${ }^{29}$ This reading, although it might not convince the historicist, would at the very least demonstrate that the Hegelian has her own way of accounting for history, which is not a simple tracing of the Herkunft of any particular concept or way of life.

\footnotetext{
${ }^{27}$ Zižek, Less than Nothing, 195.

${ }^{28}$ Ibid., 207.

${ }^{29}$ A somewhat superfluous clarification: I do not primarily refer to the 'phenomenological' tradition of Husserl, Heidegger and others with this term. I intend to designate a project analogous to that of Hegel's Phenomenology of Spirit.
} 


\section{HEGELIAN PHENOMENOLOGY}

If the genealogical approach arose as a critique of limits and an attempt to demonstrate the immanence and all-pervasiveness of discourse, the primary goal of a phenomenology is to persuade the reader that there is a way of acting, being and thinking that entails a dimension that cannot be reduced to the finite moments of the discursive plane itself, and further that this moment or distance is just what we need if we are to learn something. This distance, in other words, is what allows us to obtain a new perspective. Whether this suggests an encompassing reason working through and holding together the finite particularities of reality or, as in the Žižekian reading, a brutal crack at the heart of being and the necessity and universality of ideology, a Hegelian phenomenology is an invitation to an act of remembrance, Erinnerung, of such movements of excess to discourse.

On this understanding, there is still room for a post-Enlightenment Phenomenology of Spirit. Such a phenomenology will lead the reader through a series of symbolic 'moments' or constructs - ideal and historical - and show how, at the moment when the incompleteness of these constructs becomes explicit, one partakes in a movement of thought which is de facto a transgression of the discursive. Like a genealogy, the success or failure of this kind of phenomenology is not based on the soundness of a deductive argument. Instead, the success depends on whether one can lead the reader through these same movements and convince her that she has partaken in a process which cannot be reduced to the immanence of the discursive. It is crucial to note that this moment of excess is a moment of learning: it is not visible on the discursive level for the very reason that what is being learned is a new configuration of the world, of the possibilities revealed in the dynamic process Hegel calls 'Spirit'.

Hegel unpacks in abstract form this general approach of phenomenology in the introduction to the Phenomenology of Spirit. Here he discusses the blindness of the ordinary consciousness, the consciousness that only remains with finite particularities, or, in our terms, within the immanence of discourse. In order to go beyond ordinary consciousness and reach Science, one must gain a proper understanding of the relation between cognition and truth, between subject and object. Here one can be caught up with the classical epistemological task of inspecting one's instruments of knowledge to ensure that they give access to truth. Yet Hegel subverts this problematic of subject and object, and shows a way forward: At first (ordinary) consciousness cognises an object and takes this object to be the in-itself, or the essence, which is the True. This is the conception of truth which is the root of the epistemological dilemma: if truth is the object in-itself, then we soon entangle ourselves in quibbles about the proper instruments, or mediations, to reach the truth therein.

But then another cognition appears: 'the being-for-consciousness of this in-itself. ${ }^{30}$ This second cognition will at first be taken precisely as secondary and nothing but 'the reflection of consciousness into itself ... i.e. what consciousness has in mind is not an object, but only its knowledge of that first object.' On this understanding, the second cognition amounts to a superfluous 'I know that I know'. Nevertheless, with the appearance of this second cognition, something has happened to the object first cognised. The object

${ }^{30}$ G.W.F. Hegel, Phenomenology of the Spirit, trans. A.V. Miller (Oxford: Claredon Press, 1979), 55 (§86). 
ceases to be the in-itself, and becomes something that is the in-itself only for consciousness. And this then is the True: the being-for-consciousness of this in-itself. Or, in other words, this is the essence, or the object of consciousness. ${ }^{31}$

This transition from the cognition of ordinary consciousness to a new form of cognition is radical, the complete transformation of the notion of truth, object and essence: a transformation which pulls us straight into the heart of Hegel's conception of Science. Our interest, for now, is in Hegel's comment on this transition between the first and second cognition. The incursion of reflexivity ('I know that I know'), which first appeared as a trivial recursive cognition of one's own knowledge, actually completely alters the object itself and veils its own doings in the process:

But it is just this necessity itself, or the origination of the new object, that presents itself to consciousness without its understanding how this happens, which proceeds for us, as it were, behind the back of consciousness. ${ }^{32}$

This process, which happens 'behind the back' of consciousness, or beyond the discursive, first seems trivial to those locked into the immanence of the discursive, finite domain. Ordinary reason cannot see the radical change because it is wedded to the first cognition, and does not understand the fundamental transformation of the second. It is this problem of drawing attention to the fundamental change at the margins of the text, the invisible transgression which happens in the labour of thought, which calls for a book such as the Phenomenology. Behind our backs, under the surface of the text, the object changes so that the truth of the object is not something in-itself behind appearance, but rather a context in which the knower and the object are entangled, and where the knower is to realize that the truth has to do with how the object appears to her. In this is implied that the 'depth' of reality which so often is sought after behind the object - the Platonic Idea, if you like - is actually the depth or context in which the object and consciousness themselves reside. The change in the object is intimately connected to the performance of thinking: this speculative change happens as a result of the labour of thought, although, from the perspective of ordinary consciousness, this change comes as an added surplus to its investment in this act. This is where learning takes place, which involves a reconsideration of what counts as an object, what counts as a standard, and what counts as counting.

A phenomenology tries to convince the reader of a process of learning, or a transition in thought where something happens beyond the discursive (the reconstitution of the object, or the appearing of the non-symbolic) which is the condition of possibility of the change which happens on the discursive plane. The phenomenological of the Phenomenology is therefore not just a keen attention to and immersion to the discursive object, but also consists of a doubling of the phenomenological-a second attentiveness to the shift in context or, in other words, what goes on all around the discursive. But it is only the first, finite attentiveness which can be provided and performed by Hegel as the author. Hegel has no way of forcing the reader to see that the importance of second, reflexive cognition of the object in its relation to consciousness. The second phenomenological or attentive level, should the Phenomenology succeed, must be supplied by the reader itself. It is the wager of the phenomenological journey that the reader takes the new cognition of the 'being for consciousness of the in-itself' as a qualitative change

\footnotetext{
${ }^{31}$ Ibid.

${ }^{32}$ Ibid., 56 ( $\left.\$ 86\right)$.
} 
in the object itself, and not just an incursion of reflexivity of little importance. That is why the Phenomenology is a work of Bildung:

The series of configurations which consciousness goes through along this road is, in reality, the detailed history of the education of consciousness itself to the standpoint of Science. ${ }^{33}$

The Phenomenology provides an 'itinerary of the soul', ('Itinerarium Mentis in Deum') which the reader is called on to follow. ${ }^{34}$ Throughout the journey, the reader is invited to partake in a series of transitions or moves, and along the way Hegel tries to draw attention to the imperceptible shifts in context that adds another dimension not reducible to the discursive plane. This is remembrance as Bildung.

Žižek often presents short or extended versions of this Hegelian phenomenology, although with his devilish twist. His writings are filled with excessive digressions, obscene jokes and ironical inversions as he analyses and critiques ideological constructs. This style, however, cannot simply be reduced to a particular rhetorical choice, but must be read as his own call to remember the inauthenticity of every rational construal of the world. While it has been pointed out that Žižek at times betrays his Hegelianism by reducing cultural analysis to a series of exemplifications of his abstract universal, even if this universal is one of Hegelian-Lacanian philosophy, the pedagogical and habitual aspects of these digressions are more important than their illustrative function. ${ }^{35}$ The joke that relativizes and embarrasses a peculiar verity of the defenders of liberal democracy, for example, is not a secondary rhetorical gloss over a more substantive procedural argument. If one removed the jokes and digressions from Žižek's corpus, not much would remain. Instead, the joke is a form of training of the soul to recognise how eventually ideology will show itself as such. Ironic distance is the most serious commitment and becomes the seed of the revolutionary and political act because the ironic distance is the very gap ideologies seek to conceal.

This might explain why Milbank's genealogical approach in his debate with Žižek in The Monstrosity of Christ at times seems to miss the point. The force of Žižek's writing is not his contrived story of the three stages of Christianity (Catholic, Orthodox and Protestant), nor his claim that Meister Eckhart is on his side-a point which seems more important to Milbank than Žižek, but the phenomenological training of the reader induced through his excessive rhetoric and subversion of Christianity. Perhaps Milbank even recognises this when he turns to an extended 'phenomenological' description of how Christianity seems more true to the reality we encounter. ${ }^{36}$ Such a response is only partially adequate, however. It seems to me that the strongest critique of Žižek in particular must go beyond a simple counter-learning of another picture or way of imagining. It must show that Žižek has given up education entirely: for while Hegel always knew that the radical contingency that disrupts every present is an opportunity for learning, Žižek's phenomenology is content with teaching the necessity of the contingency itself. This is the source of the abstract nature of his writings - there is nothing new to be learned, only that everything will eventually fail. As such, the latter's ideology critique

\footnotetext{
${ }^{33}$ Ibid., $50(\$ 78)$.

${ }^{34}$ Jean Hyppolite, Genesis and Structure of Hegel's Phenomenology of Spirit (Evanston: Northwestern University Press, 1974), 11.

${ }^{35}$ Pace Simon Jarvis, "Review of the Parallax View," The Liberal, accessed October 23, 2015, http://www.theliberal.co.uk/issue_9/reviews/nf_jarvis_9.html.

${ }^{36}$ Žižek, Milbank, and Davis, The Monstrosity of Christ, $160 \mathrm{ff}$.
} 
sometimes borders on the banal. In contrast, for Hegel contingency is the opportunity for learning at least something and so for changing the way we inhabit a changing world.

\section{GENEALOGY AND PHENOMENOLOGY}

These are the contours of genealogy and phenomenology, and we have here uncovered some of the dynamics and tensions in certain contemporary encounters between a theologicalgenealogical approach and Hegelian thought. As I unpack some of the differences between the genealogical and the phenomenological, my intention is not to say that many of those theologians who write genealogies do not strive to conceive of theology in similar ways to the virtues of the phenomenological. Instead, the point is exactly this: there is a tension between the genealogical form of theological writing and the desired conception of theology, which sometimes leads to problematic distortions of the theological practice itself.

Here is the first difference we must draw attention to: Unlike the secular genealogies of a Foucault or an Agamben, a properly theological approach will, like Milbank argued, defend the idea that there is a truth which surpasses the immanence of finite discourse. Indeed, the very project of the theological appropriation of genealogy was to tell a different story; a story which affirmed the presence of transcendence, while affirming the all-pervasiveness of language and the radical historicism of the genealogical. These genealogies tell of moments of grace in history and are attempts to persuade others that these are manifestations of truth. The persuasiveness of this story, however, is dependent on the attractiveness of the story as a whole. It is only the beauty of the narrative which can arouse a desire for something that transcends the finite, a story which reaches at heart to a desire for God. The theological genealogist draws attention to an object long forgotten, trusting that this object is already witnessed to in the most interior depths of the reader. In this sense, the approach connects to a long-standing Christian tradition, which trusts that God has already planted knowledge of Himself in all people (Rom 1:20), and which enables daring rhetorical performances such as Augustine's City of God or Paul's speech at the Areopagus.

But there is a significant truth lost in this approach, which still lingers in Hegel's phenomenology. In a phenomenology, subject and object are intertwined, and the moments of excess to the finite are reflected in the very approach or 'story' itself. The wager of the Phenomenology of Spirit is not whether the reader, once having reached the final chapters about Absolute Knowledge, is persuaded by the whole story. The real bet is on the very first page: for the remembrance of the movements of the Spirit in history induced throughout the Phenomenology is inseparable from the reader's involvement with the text. The aim is not merely to tell a story of grace which has happened, which has been achieved, but to show that one can only remember by being drawn into the same Spirit to which Hegel draws attention. Remembering happens in the middle voice, somewhere between activity and passivity. ${ }^{37}$ As already mentioned, a phenomenology deals with a story of learning: it is an educative story about how we have been educated. In this way the phenomenological, as a form of manuductio-leading the reader by the hand-is in one sense more in line with certain Christian traditions than the genealogical, in so far as a properly theological writing is always an invitation to a journey of dispossesive remembrance as a form of education and, inversely,

${ }^{37}$ Pickstock, After Writing, 35. 
education as a form of remembrance. ${ }^{38}$ Here is a progression towards the remembered, an act in which something might be learned.

A historicist genealogy might avoid the developmental theodicy of which Hegelian philosophy is often accused, ${ }^{39}$ At the same time, such an approach involves a separation between the historicist narrative and the ahistorical vision of the world defended which, however much the abstract and heuristic nature of this separation is emphasized, threatens to skew our conception of remembering. An early critique of Theology and Social Theory, especially coming from Gillian Rose, was that it amounted to a defence of an ahistorical 'holy middle' only tangentially in contact with the difficult negotiations of reality. ${ }^{40}$ While Rose might have implied a full return to the dialectical with such a critique, this must not obscure the equally important insight that truth is not something achieved or final which can be retold in a simple sense. When truth can be witnessed to and remembered on a comfortably safe basis it ceases to be truth. In Rose's terms, learning is a work, it is about the next step to be made, and so truth can only be remembered if the one who remembers herself partakes in the same spirit of education that once moved the saints. There must be other means of persuasion than the mere attractiveness of the story as a whole. Here one must indeed challenge the dichotomy of ontological vision and historicist genealogy: there is a sense of the entanglement of the ontological and historical not captured by the genealogical. Instead, the story told must be a story about the particularities of how we learned and continue to learn the possibilities of thinking and being in the light of the Gospel.

There are good reasons why O'Regan seeks resources in Balthasar to remember what Hegel has forgotten. Perhaps there is, as he notes, a misremembering in Hegel's work and an equivocation in his understanding of the memoria Dei. Even so, we must not forget what Hegel remembered: that every act of remembering involves a dispossession which is uncertain in its very nature. Remembering is a difficult process of contemplation and re-enactment-it is the essence of the liturgical as a repetition which cannot happen except by an active participation. The task of the theologian, then, is to remember and to invite others to a form of remembrance more involving than hasty genealogies. The theologian is a doctor ('teacher'), and cannot teach but through manuductio or discipleship. Involved in this is perhaps a shift from a focus on the historical fluctuation of intellectual ideas to a mode of theological discourse which draws attention to what happens 'behind our backs'. It will include something like the inversion of Žižek's jokes, training the imagination of the reader to think otherwise, and thereby showing that learning is still possible. If writing is an adequate vehicle for the theological task of remembrance, that must be because reading can become an event of educative transformation.

This also means coming to terms with the sometimes ambiguous nature of genealogies: if the theological task is to tell a story of an 'other City', is this best done by recounting a story of 'right' and 'wrong' opinions? Would this exhaust what we are looking for in such a story? Whence this obsession with ideas, if the goal is to exhibit something of the beauty of grace? This problem cannot be solved by claiming that the genealogy written by the academic

\footnotetext{
${ }^{38}$ See for example Peter M. Candler, Theology, Rhetoric, Manuduction, or Reading Scripture Together on the Path to God (Grand Rapids, Mich: William B. Eerdmans Pub. Co, 2006).

${ }^{39}$ There is much that could be said against this reading. See for example John W. Burbidge, Hegel's Systematic Contingency (Basingstoke, UK ; New York: Palgrave Macmillan, 2007).

${ }^{40}$ Gillian Rose, The Broken Middle: Out of Our Ancient Society (Oxford: Wiley-Blackwell, 1992), 277-95. In an implicit reference to Rose, Milbank refuses a position that stops at 'middles forever "broken"in time'. However, that is not necessarily the implication of Rose's work. Žižek, Milbank, and Davis, The Monstrosity of Christ, 117.
} 
theologian is a different enterprise than the story of this other City - for it is only as an account of moments of grace that genealogy receives its theological justification.

This suggests that there is a union of reflection, praxis and transformation involved in a phenomenology not sufficiently taken into account by theological genealogies, which always threaten to fall into a fixation with ideas. Put differently, if the analogical vision defended by the genealogies of O'Regan and Milbank hinges on a rejection of a univocity which puts a wedge between the theoretical and the practical, then there is no inherent reason to think that a recovery of the details of Eckhart's theology will sow the seeds of transformation any more than a sustained reflection on a theatrical play, the experience of suffering, or indeed the prayerful meditation on the Via Dolorosa on Good Friday. A strong emphasis on the analogical must lead to an integration of the anagogical, the act of 'leading above'. Indeed, if there is no univocity between God and the world, semantic content can never be stabilised, multiplied to infinity and projected on God - the good can only be learned on a spiritual journey where the increase and transformation of wisdom are inseparable from practice. What matters is the moments of decision on the way: which path we choose to follow and how we learn from failure. These moments, transitions from one path to another, are moments of learning, where we must be attentive to the shift in context, that surplus or increase which cannot be accounted for by the finite text. A finite life in the middle does not result in the analogy of concepts, but the analogy of remembrance, that is, a remembrance which itself happens in the middle voice. Such stories of learning are too often forgotten by those engaged in the genealogical.

This is all to say that Hegelian phenomenology is a spiritual and pedagogical exercise in a way that Foucauldian genealogy is not, even when the latter is baptised by theologians. Although the genealogical is intertwined with a sort of spiritual practice in the Foucauldian tradition, for Foucault the genealogical allows for a sort of release from the arbitrary limits set by discursive traditions and practices. Its transformative moment is primarily negative. Although theological genealogies are also written with a positive vision in mind, this positive element is not allowed to transform the rhetorical and pedagogical practice itself. In a phenomenology there is an entanglement of history and reality, reader and text, agent, memory and event which is lost in the genealogical since the form of phenomenology more clearly involves a moment of investment. This loss of this moment, I suggest, may have detrimental effects on theological practice.

\section{LEST WE FORGET: A CONCLUSION}

In a recent review article of O'Regan's book, Aaron Riches and Sebastián Montiel lauds the former for dispelling the Hegelian ghost haunting modernity. ${ }^{41}$ Repeating O'Regan's critique, and echoing the work of William Desmond, ${ }^{42}$ they fear that Hegel's Spirit is a 'counterfeit' double of the Holy Ghost. Hegel is the character that seductively calls for Erinnerung, catching the theologian, the church, yes-modernity itself!-into his speculative net. Here, in the spectre of Hegel, hide also the ghosts of Neoplatonism and Gnosticism. Hegel's philosophy thus overtakes theology and reconfigures Christian dogma for his own speculative use, dressing up heterodoxy in the most magnificent Christian garments. The crux of Hegel's equivocation

\footnotetext{
${ }^{41}$ Aaaron Riches and Sebastián Montiel, "On Re-Membering Geist: Hegelian Hauntotheology and O'Regan's Anatomy of Misremembering," Modern Theology 32, no. 2 (2016): 268-78.

${ }^{42}$ William Desmond, Hegel's God: A Counterfeit Double?, Ashgate Studies in the History of Philosophical Theology (Aldershot, Hants, England ; Burlington, VT: Ashgate, 2003).
} 
can perhaps be formulated in the ambiguous transition from religion to philosophy in his work: Christian religion shows itself as the absolute and true religion precisely in the moment its Logos is exhausted in the clarity of the philosophical logos.

Although this might all be true on some level, it seems to me that the real value of Hegel is precisely this importance of duplicity. The duplicity, that is, of holding two things in mind at once. If we manage to do so, perhaps we might see that there is more than one way of engaging with his thought. For another lesson of Hegel is that an unequivocal Nein! always sooner or later betray its implicit-and therefore uncomprehended-relation to that which is refused. Mediation is possible, as when Graham Ward argues that Hegel is the one who shows how the incarnation made a real difference to how we reason, or when D. C. Schindler analyses the complexities of Hegel's notion of freedom. ${ }^{43}$

I touch on these somewhat parochial debates about the relevance of Hegel because the attempt to out-narrate Hegel is yet another example of what happens when the nature of genealogical discourse is not critically evaluated. Theologians should be careful with the practice of taking leave of someone, and ghosts only appear when the wounds of the past remain unresolved. This attempt to decisively expel Hegel and treat him as no 'friend' of theology, reveals the inherently ahistorical tendency of many genealogies and shows that, paradoxically, a phenomenology can be more, not less truly historical than historicist genealogies. ${ }^{44}$ Whereas Hegel is often read as understanding history as teleologically leading up to his own time, genealogies can fall into a similar trap, one that might even be worse: tracing genealogically the ideas to be vindicated can lead to a ciphering of history where actors are either good or bad depending on the extent to which they agree with the author's position. This has again to do with the fact that the ontological vision, which is charged with a kind of necessity, is not properly implicated in the historical and contingent experience of learning, of trying and failing, but only stands in an expressive relationship vis-à-vis history. In this way, a genealogy can easily become a triumphant story about those who happened to grasp this truth rightly. When this is done, one can begin deciding between the authentic and the deceitful, the friend and enemy, and thereby purge the 'real' Christian tradition from its mistakes, that is, from its process of learning. Such a story does not do justice to the development of Christian language, of political and social experience, and ultimately distorts the nature of grace as it appears in history.

Lest we forget, we should treat our historical and intellectual predecessors with care. Hegel is not one who must be saved from oblivion or unjust treatment, but he might remind us of some of the ways in which we misremember. Remembering is a spiritual exercise involving investment, dispossession and unexpected reception. The issues that arose in my analysis of some theological critiques of modern culture and thought shows that we have not yet overcome our spiritual forgetfulness. For theologians this is a call to think the third, to once again consider the relationship between genealogy and phenomenology, narrative and dialectics, mythos and logos. Furthermore, if Christian theologians are ultimately dealing with a body once mangled to the point of being beyond the powers of human remedy, we must be careful with how quickly we dress the wounds of our tradition and re-member our collective and historical bodies. In

${ }^{43}$ Graham Ward, "How Hegel Became a Philosopher: Logos and the Economy of Logic," Critical Research on Religion 1, no. 3 (2013): 270-92; D. C. Schindler, The Perfection of Freedom: Schiller, Schelling and Hegel between the Ancients and the Moderns, Veritas 8 (Eurene, Or: Cascade Books, 2012).

${ }^{44}$ Riches and Montiel, “On Re-Membering Geist: Hegelian Hauntotheology and O'Regan's Anatomy of Misremembering," 278. 
theological writing and practice, our response cannot simply be to 'tell the story otherwise'. Instead, we must attend to how such stories can be lived and enacted, how they are partial, and that something is always lost along the way. Only thus might we see that there is yet much to learn. ${ }^{45}$

${ }^{45}$ In addition to the two anonymous reviewers, I would like to thank the following for very helpful comments and suggestions: Christian Coppa; Stefan Fisher-Høyrem; Ruth Jackson; Nathan Lyons; Nandan M. Ratnam; Catherine Pickstock; Simon Ravenscroft; and Rowan Williams. 